Review

\title{
Hypoxic Signaling During Tissue Repair and Regenerative Medicine
}

\section{Tessa D. Nauta ${ }^{1,2}$, Victor W. M. van Hinsbergh ${ }^{1}$ and Pieter Koolwijk ${ }^{1, *}$}

1 Department of Physiology, Institute for Cardiovascular Research, VU University Medical Center Amsterdam, Van der Boechorststraat 7, Amsterdam 1081 BT, The Netherlands; E-Mails: t.nauta@vumc.nl (T.D.N.), v.vanhinsbergh@vumc.nl (V.W.M.H.)

2 A-Skin Nederland BV, De Boelelaan 1117, Amsterdam 1007 MB, The Netherlands

* Author to whom correspondence should be addressed; E-Mail: p.koolwijk@vumc.nl; Tel.: +31-20-444-9927; Fax: +31-20-444-8255.

External Editor: Regina M. Day

Received: 6 August 2014; in revised form: 12 September 2014 / Accepted: 15 October 2014 / Published: 31 October 2014

\begin{abstract}
In patients with chronic wounds, autologous tissue repair is often not sufficient to heal the wound. These patients might benefit from regenerative medicine or the implantation of a tissue-engineered scaffold. Both wound healing and tissue engineering is dependent on the formation of a microvascular network. This process is highly regulated by hypoxia and the transcription factors hypoxia-inducible factors- $1 \alpha$ (HIF-1 $\alpha$ ) and $-2 \alpha(\mathrm{HIF}-2 \alpha)$. Even though much is known about the function of HIF-1 $\alpha$ in wound healing, knowledge about the function of HIF-2 $\alpha$ in wound healing is lacking. This review focuses on the function of HIF- $1 \alpha$ and HIF- $2 \alpha$ in microvascular network formation, wound healing, and therapy strategies.
\end{abstract}

Keywords: angiogenesis; HIF-1 $\alpha$; HIF-2 $\alpha$; hypoxia; tissue engineering; wound healing

\section{Introduction}

Injury causes damage to the blood vessels and thereby an interrupted blood flow. Deprivation of blood supply will rapidly cause tissue hypoxia, a lack of sufficient oxygen to meet the metabolic demand of the tissue. Subsequently, an oxygen gradient will arise between affected and non-affected tissue(s) that stimulates the migration and proliferation of endothelial cells (ECs) and fibroblasts, 
and adequate angiogenesis to reconstitute normal blood supply [1]. As a result, the wound is revascularized and the oxygen concentration in the wound increases. If this process fails, a prolonged inadequate vascular supply of oxygen leads to chronic hypoxia and can cause non-healing or chronic wounds, such as venous or diabetic ulcers. These wounds generally occur in people older than 60 years of age and are caused by a combination of (1) the cellular and systemic changes of aging; (2) repeated ischemia-reperfusion injury; and (3) a chronic inflammatory environment due to prolonged infection. Acute wounds usually heal in older people without complications, but chronic wounds do not. If tissue repair fails, tissue engineering or regenerative medicine and transplantation is necessary [2].

Tissue engineering, the culture of cells on a biodegradable scaffold ex vivo, and implantation has allowed select and limited progress toward the repair of some tissues. The onset of tissue engineering [3] promised the replacement of large or complex damaged organs and regeneration of tissues as bone, liver, skin and blood vessels [4]. However, the development of complex tissues is very complicated and the lack of nutrient and oxygen delivery to and removal of waste products from developing tissues has limited the success rate of tissue engineering so far. Especially the delivery of oxygen to the highly metabolic active cells in the scaffold is a major problem resulting in reduced (hypoxia) or lack of oxygen (anoxia) within the deeper regions of the tissue-engineered scaffold [5-7]. Therefore it is important to either prevascularize tissue-engineered scaffolds by creating a blood vessel network in a scaffold in vitro or create a scaffold with an environment (matrix composition, incorporation of blood vessel-generating cells and growth factors) that facilitates rapid angiogenesis when implanted in the body. Unfortunately, this has not been realized yet, suggesting that angiogenesis is complicated.

This review focuses on the role of hypoxia and angiogenesis in wound healing and after tissue-engineered scaffold implantation. Angiogenesis is highly regulated by hypoxia and the transcription factors HIF-1 $\alpha$ and HIF-2 $\alpha$. Even though many studies and reviews have been published investigated the role of HIF-1 $\alpha$ in wound healing [8], less is known about the role of HIF-2 $\alpha$ in wound healing.

\section{Angiogenesis}

Blood vessels can be formed through different processes. Vasculogenesis is the formation of blood vessels by endothelial progenitor cells; angiogenesis refers to the sprouting of new blood vessels from existing ones, and subsequent stabilization of these new vessels by mural cells; and arteriogenesis or collateral growth includes the maturation and enlargement of smaller preexisting arterial vessels through vascular remodeling forming collateral bridges between arterial networks.

In the healthy body, endothelial cells (ECs) are quiescent; the cells hardly divide (less than once in 100-300 days), barely form new sprouts, but perform many physiological functions such as barrier between blood and surrounding tissues. Under pathological conditions, endothelial cells are activated by growth factors and inflammatory cytokines such as vascular endothelial growth factor A (VEGF-A), basic fibroblast growth factor (bFGF), platelet-derived growth factor (PDGF), and tumor necrosis factor alpha (TNF- $\alpha$ ), and the microvessels can become leaky. As a consequence, plasma proteins like fibrinogen and vitronectin leak from these vessels into the tissue and serve as building blocks for a provisional (fibrin) matrix. At the same time, activated ECs degrade their basement membrane and the extracellular matrix (ECM) through the upregulation and secretion of matrix metalloproteinases (MMPs) and the members of the plasmin-plasminogen activator (PA) pathway. Interestingly, many 
growth factors are sequestered in the ECM and are released from the ECM by these and other proteases. The ECs develop into a sprouting network of "stalk" cells and a leading "tip" cell. The "tip" cell guides the forming tube that migrates into the tissue toward gradients of chemotactic signals, whereas the proliferating "stalk" cells elongate the tube, form a lumen and form tight junctions. Once the sprout is ready to anastomize with the circulation or an adjacent sprout, a normalized vascular phenotype is induced by inhibiting the proliferation and migration of the endothelial cells. Simultaneously, mural cells including pericytes (in capillaries) and vascular smooth muscle cells (in larger blood vessels) proliferate, migrate, and differentiate, and are recruited to the immature vasculature to provide vessel stabilization and to regulate vessel perfusion. Finally, a basement membrane is formed. The initial wound healing requires a lot of energy and the recruitment of substrates and oxygen, which is met by the formation of many microvessels (the so-called granulation tissue). Once the healing is completed, a selective "pruning" of the vessels occurs, which results in a mature system with larger and smaller vessels [9-13].

\subsection{Angiogenesis in Tissue Repair}

The implantation of a tissue-engineered scaffold results in injury to the tissue, which activates the wound healing cascade. Wound healing and tissue repair consist of a highly organized sequence of complex processes that can be divided into hemostasis, inflammation, proliferation, and remodeling phases [14-17] (Figure 1). Injury causes damage to the tissue and vessels and therefore the first stage aims at controlling the local bleeding immediately, called hemostasis (seconds to hours after injury). The injured vessels constrict and deliver blood plasma, proteins and blood platelets into the wound site thereby forming a platelet plug. The damaged vessel and platelets activate the coagulation pathway resulting in the formation of a fibrin clot [18]. This fibrin meshwork enforces the platelet plug, by which two important functions are combined: a firm sealing of the damaged blood vessel and the generation of a provisional repair matrix. Indeed, activated platelets release many cytokines including VEGF-A, PDGF, bFGF, and TNF- $\alpha$ [16,19-21], which accumulate in the provisional matrix and create a chemotactic gradient that attracts many inflammatory and mesenchymal cells such as neutrophils, monocytes, macrophages, endothelial cells, and fibroblasts [22].

Inflammatory phagocytic cells infiltrate the provisional matrix, and stimulate the inflammation phase (hours to days after injury) to control and remove the injury [23]. Neutrophils (accumulating within 1-2 days post-injury) and monocytes (2-3 days) digest foreign particles, bacteria and dead or dying cells and secrete many pro-inflammatory cytokines [24]. Both the high metabolic demand of the phagocytes and the impaired supply of oxygen to the wound will cause hypoxia within the wound area. Accumulating monocytes differentiate during the inflammation phase into macrophages and these macrophages secrete growth factors and many pro-inflammatory cytokines thereby amplifying the inflammatory response. The macrophages and activated platelets in the wound site release pro-angiogenic factors [22] and induce the proliferation phase (2-10 days), which aims at regenerating the damaged tissue. This phase includes the proliferation and migration of different cell types such as fibroblasts and endothelial cells into the provisional matrix. Furthermore, hypoxic tissue cells surrounding the wound also start producing factors, in particular VEGF, which induces capillary sprouting $[25,26]$ and further attracts monocytes [27]. The angiogenic factors induce ECs forming new capillary-like sprouts, 
which invade the sealing matrix and the hypoxic wound area. This results in the formation of a microvascular network throughout the wound, providing the healing tissue with nutrients and oxygen. Fibroblasts in close proximity to the wound differentiate into myofibroblasts and invade the wound area. They contract to bring the edges of the wound together [28]. During the remodeling/regeneration phase, a delicate balance between the expansion of microvessels and fibroblasts is needed to avoid scar formation or tissue weakening [29]. Finally, the blood vessels in the granulation tissue mature to form a functional vascular network. The remodeling starts after 1-3 weeks and can last for years [15-17].

Figure 1. A schematic overview of the phases of wound healing over time. After the initial hemostasis phase, neutrophils and macrophages dominate the inflammation phase, whereas fibroblasts and endothelial cells are predominant during the proliferation phase. During the remodeling phase, fibroblasts and endothelial cells undergo apoptosis or exit the wound. Finally, the granulation tissue and vascular network remodel and mature, which can last for years. The dotted blue line indicates the time course of oxygen availability.

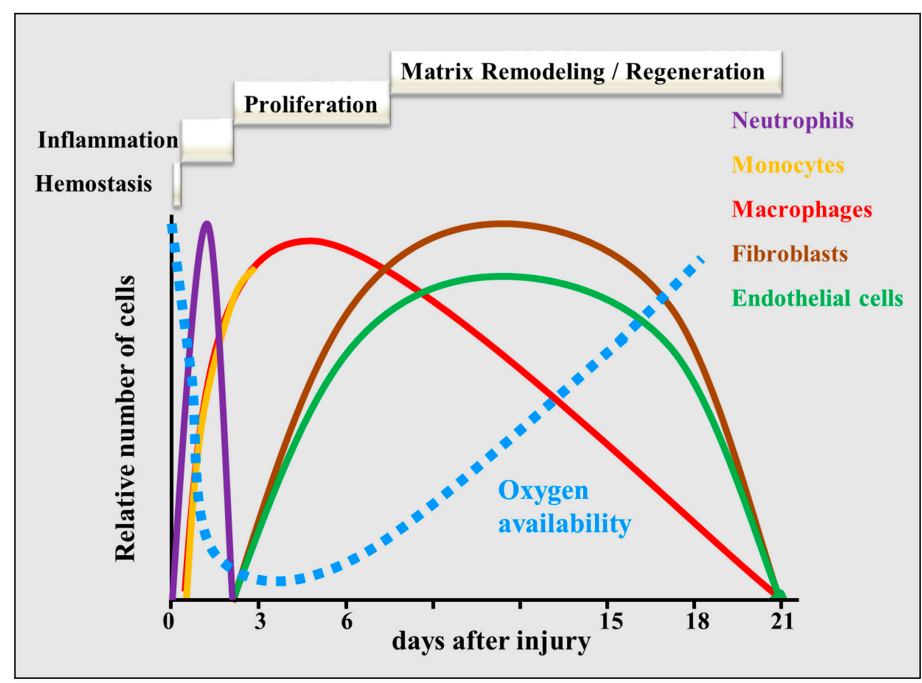

\subsection{Vascularization of a Tissue-Engineered Scaffold}

The implantation of a cellularized tissue-engineered scaffold runs through a similar sequence of events as wound healing [17]. After implantation, a surrounding fibrin meshwork is formed from the fibrinous exudate around the scaffold. Furthermore, the lack of vascularization will soon cause hypoxia within the scaffold, which within a few days can cause cell death of the whole or the central part of the scaffold [5]. Therefore rapid revascularization is required to preserve the implanted cells. The prerequisites for and sequence of this process are comparable to that of wound healing. Central in this process is the cellular response to oxygen deprivation.

\section{Cell Signaling after Oxygen Deprivation}

Although oxygen represents $21 \%$ of ambient air, within the mammalian body the oxygen concentrations vary from $13.5 \%$ in the lungs, and $5 \%-12.5 \%$ in the circulation, to $0.6 \%-5 \%$ in tissues $[30,31]$. Normally, the cardiovascular and respiratory systems ensure an adequate oxygen delivery to cells and tissues. The affected tissue area can become hypoxic [14], due to interrupted blood supply after injury or high 
oxygen consumptions as occurs in inflammation [5]. This can lead to cellular dysfunction and eventually cell death.

Cells can sense reduced oxygen levels, and respond by altering gene expression in such a way that it conserves energy, promotes cell survival and increases oxygen delivery; both mRNA transcription and protein synthesis is altered [32-34]. Many pathways are involved, including $\mathrm{Ca}^{2+}$ signaling [35], mTOR and MAP kinase pathways [35,36], internal ribosome entry sites (IRES) [37], and the unfolded protein response (UPR) [32,38]. However, the most prominent mechanism for cells to respond to hypoxic stress is through the transcription factors hypoxia-inducible factors (HIFs).

\subsection{Regulation of Hypoxia-Inducible Factors}

HIF is a heterodimer consisting of an oxygen-sensitive $\alpha$-subunit and a constitutively expressed $\beta$-subunit [39-41]. Both subunits (Figure 2) are part of the basic Helix-Loop-Helix PER-ARNT-SIM (bHLH-PAS) family of transcription factors and these domains are important for DNA binding and dimerization [39]. The HIF- $\alpha$ subunits possess several domains including an oxygen-dependent degradation domain (ODDD) and two transactivation domains (Figure 2). Both the $N$-terminal transactivation domain (N-TAD) and the $C$-terminal transactivation domain (C-TAD) are essential for the regulation of HIF-dependent gene expression [40,42].

Three isoforms of the $\alpha$-subunit exist in mammals; HIF-1 $\alpha$ [43] encoded by HIF1A, HIF-2 $\alpha$ [44] encoded by EPAS1, and HIF-3 $\alpha$ [45] encoded by HIF3A, which is expressed as three splice variants with different protein lengths (HIF-3 $\alpha_{667 a a}$, HIF-3 $\alpha_{669 a a}$ and HIF-3 $\alpha_{363 a a)}$ (Figure 2). Also three paralogues exist of the HIF- $\beta$ subunit, ARNT1 (aryl hydrocarbon receptor nuclear translocator), ARNT2 and ARNT3, but ARNT1 is the primary HIF-1 $\beta$ subunit involved in the hypoxic response [46]. In the remaining chapters HIF- $\alpha$ refers to HIF- $1 \alpha$ and HIF- $2 \alpha$ and HIF- $1 \beta$ refers to ARNT1.

Figure 2. A schematic representation of the domain structures of the HIFs. The figure shows the structural motifs basic-Helix-Loop-Helix (bHLH, in blue), PER/ARNT/SIM (PAS, in yellow), the oxygen-dependent degradation domain (ODDD, in green and also spanning the N-TAD region), the $N$-terminal and $C$-terminal transactivation domains (N-TAD and C-TAD, in pink), and the leucine zipper (LZIP, in white). The positions of the prolines hydroxylated by PHDs (prolyl-hydroxylase domain containing enzymes) are indicated by $\mathrm{P}$ and the asparagines hydroxylated by FIH (factor inhibiting HIF) are indicated by N. Adapted from [47].

bHLH PASA PAS B ODDD N-TAD C-TAD

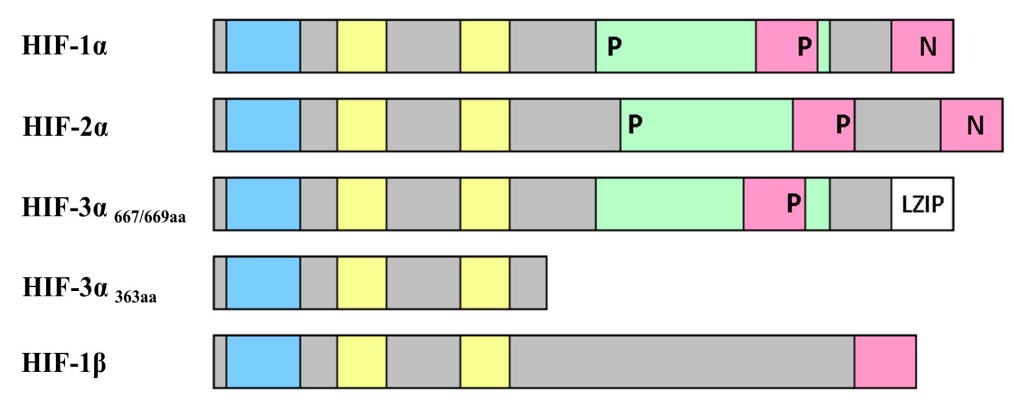


The HIF- $\alpha$ subunit is constitutively transcribed and translated, but has an extremely short half-life of $5 \mathrm{~min}$ due to constitutive degradation of the protein [39,41]. Under normal conditions (normoxia), when oxygen is present, (Figure 3), HIF- $\alpha$ is hydroxylated on two proline residues in the ODDD by prolyl-hydroxylase domain containing enzymes (PHDs) and in the C-TAD on an asparagine residue by factor inhibiting HIF (FIH) (Figure 2) [48,49]. The proline residues are located in the conserved amino acid sequence LxxLAP; two of these sequences exist in HIF-1 $\alpha$ (Pro402 and P564) and HIF-2 $\alpha$ (Pro405 and Pro531), and one sequence exists in HIF-3 $\alpha$ (Pro490). The hydroxylated proline residues form a binding site for the von Hippel Lindau tumor suppressor protein (pVHL), an E3 ubiquitin ligase, which results in ubiquitination of HIF- $\alpha$ and its subsequent degradation by the proteasome [49,50]. Hydroxylation on the asparagine residue Asn803 (for HIF-1 $\alpha$ ) and Asn847 (for HIF-2 $\alpha$ ), blocks the interaction of HIF- $\alpha$ with the co-factors p300 and Creb-binding protein (CBP), and thereby inhibits the transcription of C-TAD regulated genes. Both PHDs and FIH belong to the evolutionary conserved $\alpha$-ketoglutarate dependent $\mathrm{Fe}$ (II)-dioxygenases that require iron and ascorbate as co-factors to insert one oxygen atom into prolyl residues and the other oxygen atom to split $\alpha$-ketoglutarate into succinate and $\mathrm{CO}_{2}[48,51]$.

During hypoxia, the HIF- $\alpha$ subunit escapes hydroxylation and thereby degradation (Figure 3). Subsequently, HIF- $\alpha$ translocates to the nucleus where it forms a heterodimer with HIF- $\beta$ and this complex binds to the hypoxia-responsive elements (HREs), which contain the core sequence 5'-(A/G)CGTG-3' of the HIF-responsive genes [43,52]. These genes regulate processes such as proliferation, apoptosis/autophagy, DNA damage response, extracellular matrix metabolism, cell migration and invasion, survival, metabolism, inflammation, and an increase of oxygen delivery via erythropoiesis and angiogenesis [53,54].

The HIF- $\alpha$ subunit can also be stabilized under normal oxygen conditions or by pharmacological tools despite normal oxygen availability. Inhibition of the enzymatic function of PHDs by nitric oxide, reactive oxygen species (ROS), iron chelators and several metabolic intermediates of the tricarboxylic acid (TCA) cycle such as succinate and fumarate can stabilize HIF- $\alpha$ [48,51,55]. Furthermore, loss-of-function mutations of pVHL, which can be present in specific kidney tumors, can cause stabilization of HIF- $\alpha$ [50]. Finally, HIF- $\alpha$ can be stabilized through the activation of the phosphatidylinositol-3-kinase (PI3K), MAP kinase and phospholipase $\mathrm{C} \gamma$ (PLC $\gamma$ ) pathways upon binding of growth factors and cytokines such as epidermal growth factor (EGF) and insulin-like growth factor-1 (IGF-1) [56,57] to their tyrosine kinase receptors or G-protein coupled receptors. Moreover, proteins in the MAPK pathway can directly phosphorylate HIF-1 $\alpha[58,59]$, but it is not known whether this influences HIF-1 $\alpha$-induced gene transcription. 
Figure 3. A schematic representation of the oxygen-dependent regulation of HIF- $\alpha$. During normoxia, HIF- $\alpha$ is hydroxylated by prolyl hydroxylase domain proteins (PHDs) on proline residues. These proline residues are recognized by the protein Von Hippel Lindau ( $\mathrm{pVHL}$ ), which results in proteasomal degradation. Upon hypoxia, HIF- $\alpha$ is not hydroxylated and subsequently translocated to the nucleus. In the nucleus, HIF- $\alpha$ heterodimerizes with HIF- $\beta$; this allows the co-factors p300 and Creb-binding protein (CBP) to bind to the heterodimer. The complex binds to the hypoxia-responsive elements (HRE) and thereby induces gene expression. Adapted from [60].

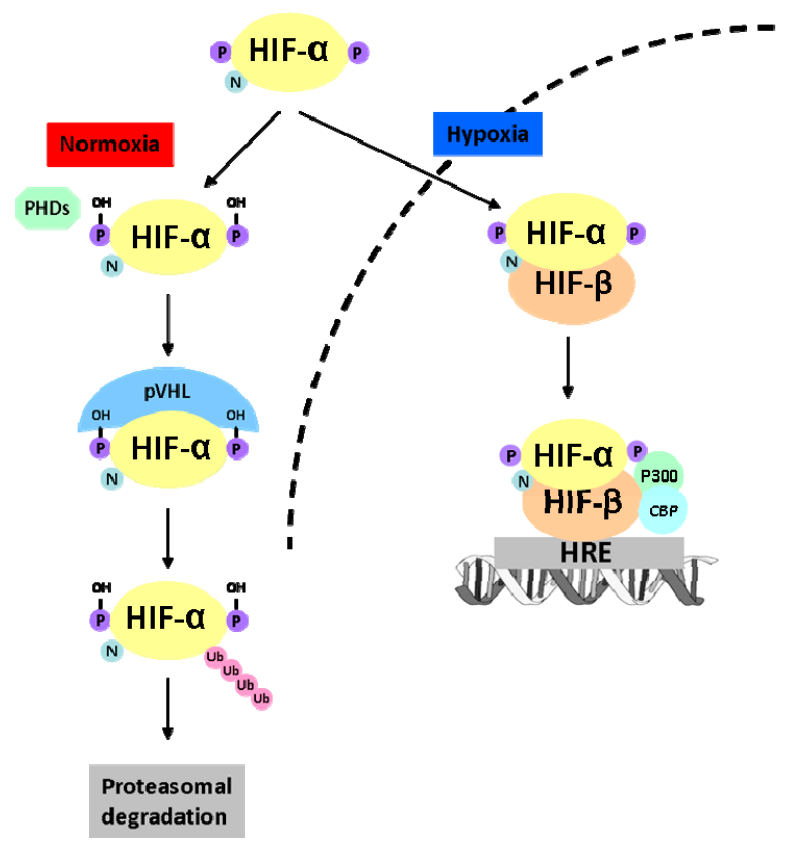

\subsection{Function of Hypoxia-Inducible Factors}

HIF- $1 \alpha$ and HIF- $2 \alpha$-induced gene expression under hypoxia share many similar target genes, but also have many unique target genes [61-63]. HIF-1 $\alpha$ and $-2 \alpha$ regulate similar genes synergistically and can partly compensate each other in ECs during embryonic development. The C-TAD and N-TAD contribute to the regulation of gene transcription and both are necessary to optimally induce gene expression [63]. The C-TAD is highly homologous between HIF-1 $\alpha$ and HIF-2 $\alpha$ and promotes the expression of HIF-1 $\alpha /$ HIF- $2 \alpha$ common genes while the N-TAD is less homologous and thus important for target gene specificity [63]. The HIF-3 $\alpha$ splice variants are also homologous to HIF-1 $\alpha$ and $-2 \alpha$, but lack the C-TAD, and the splice variant HIF-3 $\alpha_{363 a a}$ also lacks the N-TAD (Figure 2). Therefore, HIF-3 $\alpha_{363 \text { aa }}$ cannot induce gene expression and is thought to be an inhibitor of HIF-1 $\alpha$ and - $2 \alpha$-induced gene expression. The splice variants HIF-3 $\alpha_{667 a a}$ and HIF-3 $\alpha_{669}$ aa can induce gene expression, but only very weakly $[45,64,65]$.

Although HIF-1 $\alpha$ and HIF-2 $\alpha$ respond to similar stimuli in the cell, they often control different pathways. A central adaptation to hypoxia is the shift toward anaerobic glycolysis. HIF-1 $\alpha$ guides this shift by promoting the expression of glucose transporters and glycolytic enzymes $[62,63,66,67]$. Moreover, during hypoxia, the mitochondria release ROS, which can cause DNA damage. HIF- $2 \alpha$ suppresses aberrant ROS accumulation by regulating the expression of antioxidant enzymes, such as 
superoxide dismutase-2 (SOD2) and heme oxygenase 1 (HMOX1) [68,69]. Moreover, HIF-1 $\alpha$ and HIF-2 $\alpha$ have antagonistic effects on adult and embryonic angiogenesis [70], which will be discussed in detail below.

\section{HIFs and Angiogenesis}

\section{1. $H I F-1 \alpha$}

Prenatal knockout of HIF1A in mice is embryonic lethal due to neural, cardiac and angiogenic defects [67,71-73]. The HIF1A ${ }^{-/}$embryos appear normal at day E8.5, but at day E9.5 these embryos display vascular defects such as inadequate vessel formation and abnormal large endothelial-lined vascular structures that are not rescued by HIF-2 $\alpha[67,74]$. The embryonic yolk sacs completely lack organization in the branching of the vasculature, although the vessels are fully formed containing erythrocytes [72]. Also, the dorsal aorta and atrium contain erythrocytes in HIF1A null embryos [73].

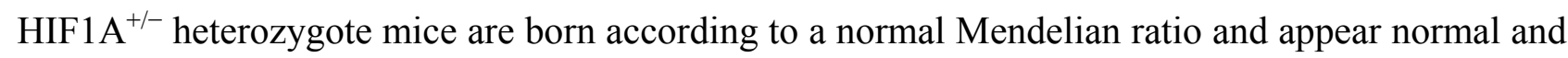
healthy with normal hematocrit levels $[67,71,75]$, but the mice display impaired pulmonary adaptation to chronic hypoxia [75].

Interestingly, endothelial-specific HIF1A-deficient mice develop normally, suggesting that for proper vascularization during embryonic development, interaction with non-endothelial cells is pivotal. However, these mice could barely form vessels in tumors or in a repair setting in vivo. Notwithstanding, erythrocytes were visible in the few vessels that developed, suggesting that those vessels were functional [61]. In line with an impaired angiogenesis in a pathological setting, under reduced oxygen conditions, the proliferation, migration, invasion and tube formation was hampered in HIF1A-deficient endothelial cells [61,76] or embryonic stem cells [67]. Moreover, HIF1A null endothelial cells could not form tubular networks in hypoxia in vitro [61].

Clearly, HIF-1 $\alpha$ stimulates processes involved in vessel sprouting and neovascularization such as endothelial cell proliferation, migration, and tube formation.

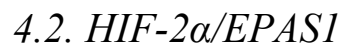

While HIF-2 $\alpha$ (also called EPAS1, endothelial PAS domain containing protein 1) is expressed more selectively than HIF-1 $\alpha$, its expression in endothelial cells is relatively strong [44]. It is also encountered in several other cell types, such as hematopoietic cells [77] and keratinocytes [78].

The generation of HIF $2 \mathrm{~A}^{-/-}$mice resulted in embryonic or perinatal lethality, but the severity of vascular defects depended on the genetic background of the mice. HIF2A ${ }^{-/}$embryos intercrossed between mice with the same genetic backgrounds showed severe vascular defects and died before day E12.5 [68,79,80]. However, HIF2A ${ }^{-/-}$embryos intercrossed from different mouse strains showed less severe vascular defects, but the degree of the defects varied, probably due to compensating mechanisms $[68,77,79,81]$. The yolk sacs of HIF2A ${ }^{-/}$embryos showed misarranged endothelial cells and smaller blood vessels that merged into extensive endothelial sheets. Some organs showed normal vascular development but in other organs the small vessels failed to remodel into larger vessels. And if large vessels were formed, they were leaky. Re-expression of HIF-2 $\alpha$ in endothelial cells in HIF $2 \mathrm{~A}^{-/-}$ 
embryos could rescue $30 \%$ of the embryos beyond day E12.5 and large vessels were observed that branched into progressively smaller sprouts [80].

Postnatal whole body HIF2A deletion also resulted in reduced erythrocyte levels, hematocrit values and hemoglobin levels leading to anemia. Moreover, hematopoietic progenitor cells had reduced differentiation levels in postnatal HIF2 $\mathrm{A}^{-/-}$mice [82].

The HIF $2 \mathrm{~A}^{+/-}$heterozygote mice were born according a Mendelian ratio and showed no vascular defects in the heart, kidneys or retina and had normal hematocrit levels $[77,79,83,84]$, but the retinas in HIF $2 \mathrm{~A}^{+/-}$mice showed reduced neovascularization after oxygen-induced retinopathy [84].

Endothelial cell-specific HIF2A ${ }^{-/-}$mice exhibited increased acute vascular leakage in response to VEGF stimulation and defective tumor neovascularization [70]. HIF-2 $\alpha$-deficient endothelial cells display increased migration, invasion and tube formation, reduced adhesion, but no difference in proliferation or viability in vitro under hypoxic conditions [70,76,79]. Also, more new vessels were formed in endothelial-specific $\mathrm{HIF} 2 \mathrm{~A}^{-/}$mice, these vessels failed to remodel into mature, functional blood vessels in vivo [76].

Clearly, HIF-2 $\alpha$ is involved in restricting angiogenesis-related processes like endothelial cell migration and sprouting and promotes vessel remodeling into mature, functional vessels.

\section{3. $H I F-3 \alpha$}

HIF-3 $\alpha$ consists of three human splice variants HIF-3 $\alpha 667$ aa (in mouse HIF-3 $\alpha$ ), HIF-3 $\alpha 363$ aa (in mouse IPAS), and HIF-3 $\alpha_{66}$ aa (in mouse NEPAS), which are homologous to HIF-1 $\alpha$ and HIF-2 $\alpha$, but they cannot induce gene expression or only very weakly [45,64,65].

Moreover, HIF-3 $\alpha$ mRNA is increased after exposure to hypoxia, suggesting that the HIF-3 $\alpha$

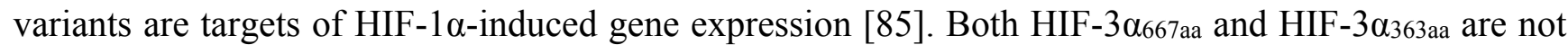
detectable in embryos [64], but are expressed in adult stages e.g. in the brain and eyes [45]. HIF-3 $\alpha_{669}$ aa is exclusively expressed in the late embryonic stages and early postnatal stages with the highest expression in the vessels and the heart [64].

Cells expressing HIF-1 $\alpha$ and HIF-2 $\alpha$ and one of the HIF-3 $\alpha$ variants show decreased levels of hypoxia-induced gene expression $[45,64,65]$. All the HIF-3 $\alpha$ splice variants can bind directly to HIF-1 $\alpha$, HIF- $2 \alpha$ and HIF-1 $\beta$. The binding of HIF- $3 \alpha$ to HIF- $1 \alpha$ prevents the translocation of HIF- $1 \alpha$ to the nucleus [65]. Moreover, the binding of HIF-3 $\alpha$ to HIF-1 $\alpha$, HIF-2 $\alpha$ or HIF-1 $\beta$ inhibits the heterodimerization of HIF-1 $\alpha$-HIF- $1 \beta$ or HIF- $\alpha-H I F-1 \beta$ and thereby HIF- $1 \alpha /$ HIF- $2 \alpha$-mediated gene expression. Overexpression of HIF-1 $\beta$ reversed the HIF-3 $\alpha$-mediated suppression of gene expression [64]. Apparently, the HIF-3 $\alpha$ splice variants function as dominant negative regulators of HIF- $1 \alpha$ and HIF- $2 \alpha$-mediated gene expression when HIF-1 $\beta$ is limiting.

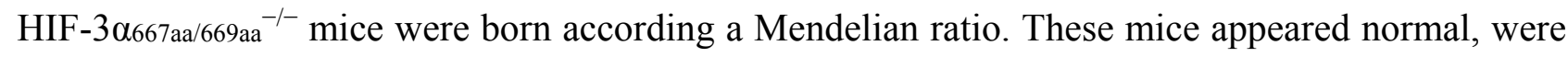
viable and fertile, but lung formation was delayed and lung remodeling was impaired. Moreover, the right atrium and ventricle was slightly enlarged, but the myocardium contained many microcapillaries [64].

Epithelial cells in the cornea, an avascular and hypoxic tissue, express high concentrations of

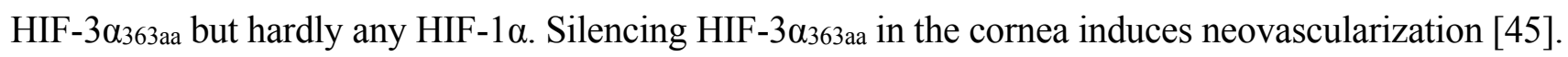

These data suggest that the splice variants of HIF-3 $\alpha$ function as dominant negative regulators of HIF- $1 \alpha$ and HIF- $2 \alpha$ by binding to HIF- $1 \alpha$, HIF- $2 \alpha$ and HIF- $1 \beta$. However, the HIF- $3 \alpha$ splice variants 
are not global repressors of the hypoxia-induced gene response, but function more locally in various tissues such as the cornea.

\subsection{HIF-1 $\beta / A R N T$}

Whole body $\mathrm{ARNT}^{-/-}$embryos are embryonic lethal and die before day E10.5 due to defects in angiogenesis, cardiogenesis, hematopoiesis and placentation [86-90]. The embryos exhibited improper vessel formation, remodeling and maturation. The yolk sacs of $\mathrm{ARNT}^{-/-}$embryos at day E8.5 appeared normal and had a normal vascular development. At day E9.5 most of the embryonic yolk sacs contained no vasculature and other yolk sacs contained some vessels that were not filled with blood. Moreover, the yolk sacs showed defective endothelial remodeling; the endothelial cells were fused with each other and the few capillaries that were present in the yolk sacs fused into enlarged structures [87,90]. Also the heart and dorsal aorta contained less endothelial cells resulting in a disorganized vascular network.

$\mathrm{ARNT}^{+/-}$heterozygote mice were born according a Mendelian ratio and all pups were viable [86,90].

Ninety percent of EC-specific ARNT ${ }^{-/-}$embryos died prenatal [91] and these embryos had no blood in their umbilical cords or placentas. Although the hearts and livers of these embryos showed lesions with hemorrhages and contained more areas lacking vasculature compared with wild-type embryos, the development and functioning of most organs were not affected by ARNT deficiency in endothelial cells. Surprisingly, the live EC-specific $\mathrm{ARNT}^{-/-}$embryos and their yolk sacs were indistinguishable from wild-type embryos. These mice were fertile and appeared normal.

These data suggest that HIF-1 $\beta$ seems to be involved in embryonic and yolk sac angiogenesis, but not in vasculogenesis.

\section{HIF-1 $\alpha$ and HIF-2 $\alpha$ Expression During Wound Healing}

There is much known about the role of HIF-1 $\alpha$ in wound healing. However, recently a paper was published investigating the role of HIF-2 $\alpha$ in wound healing.

HIF-1 $\alpha$ expression is increased after tissue injury through hypoxia-dependent and -independent mechanisms. Immediately after injury, even before detectable hypoxia, TNF- $\alpha$ induces HIF- $1 \alpha$ expression in primary inflammatory cells $[92,93]$. In the later inflammatory phase, hypoxia is present and stabilizes the HIF-1 $\alpha$ protein [93]. Moreover, during the inflammatory response, HIF-1 $\alpha$ and HIF-2 $\alpha$ play important roles in the secretion of pro-inflammatory cytokines in macrophages $[94,95]$.

In animal models, the effect of HIF- $1 \alpha$ in multiple wounding models was examined. During spontaneous wound healing in the skin, HIF-1 $\alpha$ was abundantly expressed in keratinocytes invading the provisional matrix and re-epithelializing the wound and HIF-1 $\alpha$ is involved in the formation of new capillary sprouts invading the wound clot $[61,96]$. Moreover, in burned tissue, HIF-1 $\alpha$ protein levels increased, resulting in the mobilization of circulating angiogenic cells, and in vessel formation at the healing margin of granulation tissue [97,98]. Burn wounds in mice with HIF1A deletion exhibited delayed wound closure and reduced vascularization [99]. During acute gastric mucosal injury and esophageal ulcer induction, mainly the endothelial cells adjacent to the necrotic tissue of the wound bed and regenerating microvessels express increased HIF-1 $\alpha$ protein levels $[100,101]$.

Chronic wounds are characterized by persistent inflammation, lack of proliferative cells, and increased proteolytic activity preventing sufficient extracellular matrix deposition [102]. Reduced levels of 
HIF-1 $\alpha$ protein have been documented in a number of chronic conditions associated with impaired wound healing including diabetes and aging [98,103,104]. In diabetic wounds, high glucose concentrations impair both HIF-1 $\alpha$ stabilization via VHL-mediated degradation although HIF-1 $\alpha$ mRNA is expressed $[103,105,106]$ and HIF-1 $\alpha$ induced gene transcription by influencing the activity of the N-TAD and C-TAD. Therefore, despite the increased hypoxia in diabetic wounds, HIF-1 $\alpha$ protein levels are decreased and transcriptional activity is reduced. Moreover, during aging, PHD levels are upregulated leading to increased HIF-1 $\alpha$ degradation, even under hypoxic conditions [104].

Surprisingly, the impaired wound healing in diabetic or aged wounds seems to be reversible; upon over-expression of a constitutively active form of HIF-1 $\alpha$, HIF-1 $\alpha$ protein levels were increased in the granulation tissue, and the epithelial regeneration and angiogenesis in both the wound bed and proximal skin were improved. Moreover, the number of total vessels was increased and the overall diabetic wound healing was improved [103,105,107,108].

HIF-2 $\alpha$ protein was stabilized at the wound margin in full-thickness dermal wounds with the highest expression after 5 days. Surprisingly, in contrast to HIF- $1 \alpha$, HIF-2 $\alpha$ probably impairs wound healing since HIF $2 \mathrm{~A}^{-/-}$in keratinocytes showed increased migration and wound healing [78]. In addition, endothelial-specific deletion of HIF2A in mice resulted in increased sprouting, but less functional vessels [76].

\section{Tissue Repair/Tissue Engineering}

Comparable to healthy tissue, injured tissue and tissue-engineered scaffolds require blood vessels for their oxygen and nutrient delivery and waste product removal. However, oxygen diffusion is limited in a cellular tissue-engineered scaffold [7,109], and cells located more than $100 \mu \mathrm{m}$ from the nearest capillary blood vessel experience hypoxia [5,6]. Therefore, new microvascular network formation is a critical component of wound healing and tissue regeneration [110-113]. Moreover, blood vessels transport signaling molecules such as angiogenic factors to stimulate endothelial sprouting during wound healing and reestablish a connection from the avascular zone to the circulation.

\subsection{Therapeutic Angiogenesis}

Angiogenesis is dependent on a proper balance between pro- and anti-angiogenic factors [9] and between sprout-inducing and -inhibiting factors [13]. An imbalance between these factors will cause chaotic, irregular, and leaky vessels with many avascular and hypoxic areas, a situation often observed in tumors [114-116]. Tumor cells proliferate fast and therefore tumors frequently have hypoxic areas. These hypoxic areas stimulate tumor angiogenesis and the newly formed vessels are involved in the metastatic characteristics of tumors. Moreover, the hypoxic environment and leaky vessels counteract tumor therapy; chemotherapy cannot be delivered to the tumor due to poor perfusion of the vessels [116] and oxygen is required for the cytotoxic effect of ionizing radiation, which is inhibited in hypoxic environments [117]. Therefore, a delicate balance between stimulating and inhibiting angiogenesis is very important. 


\subsubsection{Inhibiting Angiogenesis}

Therapeutic inhibition of angiogenesis appears to be very complicated. Inhibiting angiogenesis was thought to be a treatment for tumors. Even though in different tumor mouse models blocking VEGF or the VEGF receptor 2 (VEGFR2 or KDR) with inhibitors was shown to effectively reduce tumor vasculature or disrupt the existing vasculature, the tumors were more aggressive and invasive [114,118]. And after the treatment was stopped, the tumor vessels regrew to the same number and irregularity as before treatment [114].

Although wound healing requires angiogenesis [113], excess connective tissue density and excessive newly formed vessels could reduce the overall quality of the healed wound, as demonstrated by the use of a broad-spectrum angiogenesis inhibitor [119].

\subsubsection{Stimulating Angiogenesis}

The stimulation of angiogenesis is more complicated than initially thought. The formation of initial sprouting during angiogenesis is highly stimulated by growth factors and the majority of these factors are stimulated by hypoxia and the HIFs, which induce, amongst others, the potent angiogenesis stimulator VEGF-A [9,120]. Hypoxia and the HIFs stimulate processes such as endothelial cell survival, proliferation, capillary sprouting and the directed migration of endothelial cells toward a chemotactic gradient, as well as the recruitment of pericytes and the eventual inhibition of proliferation and migration once a functional sprout has been formed $[9,10,12]$.

Injection of high concentrations of VEGF induced tortuous and leaky newly formed vessels in rodents [121,122]. Injection of high concentrations of VEGF, however, was not sufficient to induce neovascularization in the retina of primates [121]. Moreover, treatment of wounds with VEGF did not improve wound healing, and high concentrations even impaired wound healing [123].

It is thought that the usage of autologous stem cells could be beneficial for repairing or regenerating injured tissues. Recently, Sánchez Muñoz et al. [124] showed in an artificial skin substitute model of fibroblasts and keratinocytes embedded in a fibrin matrix that capillary-like structures were only formed when human umbilical cord endothelial cells were implanted in the fibrin matrix in combination with human adipose-derived mesenchymal stem cells. These capillary-like structures were lined with $\mathrm{CD} 31^{+}$and $\mathrm{vWF}^{+}$cells, suggesting that these lining cells are endothelial cells.

\subsection{Angiogenesis and Hypoxia as Therapeutic Tools in Tissue Engineering and Tissue Repair}

A prevascularized scaffold requires the isolation of cells from the patient, followed by in vitro expansion and conditioning of cells within the scaffold before implantation. However, stimulating the formation of a vascular network in vitro is complicated. It was thought that endothelial cells cultured in a matrix in the presence or absence of angiogenic factors in vitro could generate a primitive vascular network that would be sufficient to vascularize the scaffold. Although the primitive vascular network was formed and could form anastomoses with the host vessels [125,126], the engineered vessels were only functional upon introduction of anti-apoptotic genes [110]. During the transfer of a prevascularized tissue-engineered scaffold from an oxygenated in vitro environment to a less oxygenated in vivo implantation site, the oxygen level drops. Moreover, the generated vascular system 
has to connect to the vascular network of the patient soon after implantation to maintain viability of the seeded cells [113]; the cells on the outside of the tissue-engineered scaffold consume high amounts of oxygen resulting in an oxygen gradient from the outside toward the inner part of the scaffold, where almost no oxygen is available [5,6,109]. The result is cell death and degradation of the non-perfused capillary network $[5,127]$.

A similar oxygen gradient is present in injured tissues and this oxygen gradient stimulates the expression and secretion of cytokines and growth factors and therefore the migration and proliferation of endothelial cells and fibroblasts. Moreover, epithelialization is increased in hypoxia and angiogenesis is stimulated $[1,25,128,129]$ leading to revascularization in the newly formed granulation tissue and subsequent wound healing. Therefore, it has been proposed that short-term exposure to hypoxia stimulates tissue repair and angiogenesis [130].

However, if the decreased oxygen levels persist inside the scaffold, the cells will die. Prolonged severe hypoxia decreases the proliferation rate and granulation tissue synthesis in fibroblasts in vitro, causes vascular degeneration, and eventually endothelial cells will undergo apoptosis [102,128]. Moreover, clinical animal studies have shown that wound healing is delayed under prolonged hypoxia and low oxygen levels were found in non-healing chronic wounds. The delay in wound healing was due to reduced granulation tissue production and delayed epithelialization [131-133], and lack of oxidants required for the prevention of wound infection [130,134-136]. In vivo, oxygen levels between $0.5 \%-1.5 \%$ were measured at the threshold between the epicenter of the wound and the granulation tissue; leukocytes were observed in this area whereas proliferating fibroblasts were only found in areas with higher oxygen levels.

\subsection{HIF-1 $\alpha$ and HIF-2 $\alpha$ as Therapy?}

As mentioned above, tissue repair and tissue engineering require the formation of a mature vascular network and a proper connection to the host vessels. The induction of a mature vascular network is dependent on a precise balance of many pro- and anti-angiogenic factors. In this induction, HIF-1 $\alpha$ and HIF-2 $\alpha$ play in part different roles. Amongst many functions, HIF-1 $\alpha$ is a strong inducer of capillary sprout formation in particular by inducing VEGF-A transcription in all cells [26]. HIF-2 $\alpha$ has more of a balancing role, not only by a more selective expression, but in particular because in endothelial cells it induces sprout stabilization [76] and its VEGF-inducing capacity is weaker than that of HIF-1 $\alpha$ [137].

Overexpression of HIF-1 $\alpha$ by gene transfer [138] or by blocking HIF-1 $\alpha$ degradation [139-143] can stimulate angiogenesis and non-leaky vessels in multiple animal studies. Reduced levels of HIF-1 $\alpha$ impair angiogenesis [97]. Interestingly, overexpression of HIF-1 $\alpha$ in chronic wounds in diabetic or aged mice improved the healing, granulation tissue formation, and angiogenesis in both the wound bed and proximal skin $[103,105,108]$. The iron chelator deferoxamine increased the binding of HIF-1 $\alpha$ to its co-factor p300 and thereby normalized the high-glucose induced reduction in VEGF expression. This resulted in increased neovascularization, granulation tissue formation and enhanced wound healing rate in diabetic mice [107]. Therefore topical application of deferoxamine might be a potential candidate for improving wound healing in diabetic patients that should be further evaluated.

On the other hand, consistent increased levels of HIF-1 $\alpha$, but not HIF-2 $\alpha$, are associated with hypertrophic scars and system sclerosis. These scars express increased levels of profibrotic and growth 
factors and contain many hyperproliferative cells, excessive deposition of collagen and increased vasculature $[144,145]$. Furthermore, HIF-1 $\alpha$ is highly expressed in many tumors due to hypoxia-dependent and -independent mechanisms and is correlated with tumor growth and a more aggressive tumor phenotype [53,146,147]. Enhancement of HIF-1 activity might therefore be counterindicated in tumor or tumor-prone individuals. Indeed, several HIF-1 inhibitors are in clinical trials [148], and these inhibitors reduce tumor vascularization and tumor growth in mice [149]. On the contrary, selective HIF-1 modulating agents, like PHD inhibitors already receive (clinical) interest as a means to increase erythropoietin production in the kidney and subsequent erythropoiesis [150,151].

HIF-2 $\alpha$ was expressed in wounds with the highest expression a couple of days after wounding. This suggests an involvement in wound repair. Reducing HIF-2 $\alpha$ expression in keratinocytes increased the rate of wound healing [78]. Moreover, mice with an endothelial cell-specific HIF2A deletion produced increased numbers of small vessels and capillaries but failed to remodel them into mature, functional blood vessels. In addition, deletion of delta-like 4 (D114), a target gene of HIF-2 $\alpha$, showed an increase in capillary formation but these capillaries were disorganized [76]. These observations are compatible with a capillary-stabilizing role of HIF-2 $\alpha$ [76]. This makes HIF-2 $\alpha$ a potentially attractive target for modulating angiogenesis in tissue repair.

HIF- $2 \alpha$ can be modulated by direct stimulation of its expression or indirectly by influencing factors that modulate HIF-2 $\alpha$ expression. For example, EC-specific deletion of KEAP1 (Kelch-like ECH-associated protein 1) in mice reduced the hypoxia-induced HIF-2 $\alpha$ and Dll4 expression, while it increased Nrf2 (NF-E2-related factor 2) expression in murine retinas. The KEAP1 ${ }^{-/}$retinas showed hypersprouting, similar as observed when D114 was blocked in wild-type retinas. Silencing of KEAP1 also increased HIF-1 $\alpha$ expression in hypoxia, suggesting that silencing KEAP1 disturbs the balance between HIF-1 $\alpha$ and HIF-2 $\alpha$ toward sprouting [152]. An interesting alternative approach was reported by Chen et al. [153], who silenced the tumor suppressor Int6/eIF3e in normoxic mice. Silencing of Int6/eIF3e resulted in a 2-fold increased expression of HIF-2 $\alpha$, without affecting HIF-1 $\alpha$. Mice injected with siRNA-Int6 showed enhanced neovascularization and excisional wound healing both in control and diabetic mice. This increase in neovascularization was completely abolished by silencing HIF-2 $\alpha$ simultaneously, suggesting that this improvement was dependent on HIF-2 $\alpha$. In this particular condition, HIF-2 $\alpha$ stimulated both vascular sprouting and stabilization.

Before translation to humans can be made, additional aspects need to be taken into account, in particular regarding the use of HIF-modulating agents in chronic wounds. One has to consider that in advanced diabetes patients often the proximal arteries have also been affected, which interferes with an adequate blood supply to the chronic wound and may require additional treatment. Mice with an EC-specific HIF-2 $\alpha$ deletion display less collateral arteries and smooth muscle recruitment to the collateral arteries after femoral artery ligation [76] indicating that HIF-2 $\alpha$ also plays a role in arterial remodeling and improving blood supply. Moreover, albeit HIF-1 $\alpha$ is highly expressed in limb muscles exposed to short-term hypoxia, where it can function as a stimulator of wound healing, in limb muscles with chronic hypoxia, HIF-1 $\alpha$ is hardly expressed [154]. This indicates that a precise balance between HIF- $1 \alpha$ and HIF- $2 \alpha$ is necessary for a proper induction of sprouting and maturation of blood vessels. 


\section{Conclusions}

Almost every stage of normal wound healing is influenced by hypoxia and HIFs. In response to hypoxia, HIF-1 $\alpha$ and HIF-2 $\alpha$ are stabilized and induce the expression of many downstream target genes involved in many processes including angiogenesis, proliferation and cell survival. HIF-1 $\alpha$ stimulates angiogenic processes involved in vessel sprouting and neovascularization whereas HIF-2 $\alpha$ promotes vessel remodeling into mature, functional vessels. Deficiency of HIF-1 $\alpha$ can lead to non-healing chronic wounds whereas overexpression of HIF-1 $\alpha$ can improve wound healing but could also induce hypertrophic scars and tumor growth. HIF-2 $\alpha$ impairs wound healing and deficiency of HIF- $2 \alpha$ improves wound healing. Modulation of HIF- $1 \alpha$ or HIF- $2 \alpha$ expression through both positive and negative regulators may provide a promising therapeutic to improve wound healing. However, the complexity of the HIF signaling pathway and existence of multiple HIF and PHD isoforms present a continuing challenge to the development of clinically effective targeted HIF therapies. Manipulation of specific downstream targets of HIF-1 $\alpha$ and HIF-2 $\alpha$ might support improved wound healing in chronic hypoxic wounds and the success of tissue-engineered scaffold implantation.

\section{Acknowledgments}

This work was supported by a grant of the Netherlands Institute for Regenerative Medicine (NIRM).

\section{Author Contributions}

Tessa D. Nauta, Victor W. M. van Hinsbergh and Pieter Koolwijk wrote the manuscript together.

\section{Conflicts of Interest}

The authors declare no conflict of interest.

\section{References}

1. Niinikoski, J.; Hunt, T.K.; Dunphy, J.E. Oxygen supply in healing tissue. Am. J. Surg. 1972, 123, 247-252.

2. Mustoe, T. Understanding chronic wounds: A unifying hypothesis on their pathogenesis and implications for therapy. Am. J. Surg. 2004, 187, 65S-70S.

3. Yannas, I.V; Burke, J.F.; Orgill, D.P.; Skrabut, E.M. Wound tissue can utilize a polymeric template to synthesize a functional extension of skin. Science 1982, 215, 174-176.

4. Langer, R. Tissue engineering. Mol. Ther. 2000, 1, 12-15.

5. Radisic, M.; Malda, J.; Epping, E.; Geng, W.; Langer, R.; Vunjak-Novakovic, G. Oxygen gradients correlate with cell density and cell viability in engineered cardiac tissue. Biotechnol. Bioeng. 2006, 93, 332-343.

6. Carrier, R.L.; Rupnick, M.; Langer, R.; Schoen, F.J.; Freed, L.E.; Vunjak-Novakovic, G. Perfusion improves tissue architecture of engineered cardiac muscle. Tissue Eng. 2002, 8, 175-188. 
7. Malda, J.; Rouwkema, J.; Martens, D.E.; le Comte, E.P.; Kooy, F.K.; Tramper, J.; van Blitterswijk, C.A.; Riesle, J. Oxygen gradients in tissue-engineered PEGT/PBT cartilaginous constructs: Measurement and modeling. Biotechnol. Bioeng. 2004, 86, 9-18.

8. Hong, W.X.; Hu, M.S.; Esquivel, M.; Liang, G.Y.; Rennert, R.C.; McArdle, A.; Paik, K.J.; Duscher, D.; Gurtner, G.C.; Lorenz, H.P.; et al. The role of hypoxia-inducible factor in wound healing. Adv. Wound Care 2014, 3, 390-399.

9. Krock, B.L.; Skuli, N.; Simon, M.C. Hypoxia-induced angiogenesis: Good and evil. Genes Cancer 2011, 2, 1117-1133.

10. Risau, W. Mechanisms of angiogenesis. Nature 1997, 6626, 671-674.

11. Coulon, C.; Georgiadou, M.; Roncal, C.; de Bock, K.; Langenberg, T.; Carmeliet, P. From vessel sprouting to normalization: Role of the prolyl hydroxylase domain protein/hypoxia-inducible factor oxygen-sensing machinery. Arterioscler. Thromb. Vasc. Biol. 2010, 30, 2331-2336.

12. Jain, R.K. Molecular regulation of vessel maturation. Nat. Med. 2003, 9, 685-693.

13. Potente, M.; Gerhardt, H.; Carmeliet, P. Basic and therapeutic aspects of angiogenesis. Cell 2011, 146, 873-887.

14. Remensnyder, J.P.; Majno, G. Oxygen gradients in healing wounds. Am. J. Pathol. 1968, 52, 301-323.

15. Lokmic, Z.; Musyoka, J.; Hewitson, T.D.; Darby, I.A. Hypoxia and hypoxia signaling in tissue repair and fibrosis. Int. Rev. Cell Mol. Biol. 2012, 296, 139-185.

16. Broughton, G., 2nd.; Janis, J.E.; Attinger, C.E. The basic science of wound healing. Plast. Reconstr. Surg. 2006, 117, 12S-34S.

17. Anderson, J. Biological responses to materials. Annu. Rev. Mater. Res. 2001, 31, 81-110.

18. Laurens, N.; Koolwijk, P.; de Maat, M.P.M. Fibrin structure and wound healing. J. Thromb. Haemost. 2006, 4, 932-939.

19. Martin, P. Wound healing-Aiming for perfect skin regeneration. Science 1997, 276, 75-81.

20. Baumgartner, H.R.; Hosang, M. Platelets, platelet-derived growth factor and arteriosclerosis. Experientia 1988, 44, 109-112.

21. Möhle, R.; Green, D.; Moore, M.A.; Nachman, R.L.; Rafii, S. Constitutive production and thrombin-induced release of vascular endothelial growth factor by human megakaryocytes and platelets. Proc. Natl. Acad. Sci. USA 1997, 94, 663-668.

22. Leibovich, S.J.; Ross, R. The role of the macrophage in wound repair. Am. J. Pathol. 1975, 78, 71-100.

23. Martin, P.; Leibovich, S.J. Inflammatory cells during wound repair: The good, the bad and the ugly. Trends Cell Biol. 2005, 15, 599-607.

24. DiPietro, L.A. Wound healing: The role of the macrophage and other immune cells. Shock 1995, 4, 233-240.

25. Shweiki, D.; Itin, A.; Soffer, D.; Keshet, E. Vascular endothelial growth factor induced by hypoxia may mediate hypoxia-initiated angiogenesis. Nature 1992, 359, 843-845.

26. Yamakawa, M.; Liu, L.X.; Date, T.; Belanger, A.J.; Vincent, K.A.; Akita, G.Y.; Kuriyama, T.; Cheng, S.H.; Gregory, R.J.; Jiang, C. Hypoxia-inducible factor-1 mediates activation of cultured vascular endothelial cells by inducing multiple angiogenic factors. Circ. Res. 2003, 93, 664-673. 
27. Clauss, M.; Gerlach, M.; Gerlach, H.; Brett, J.; Wang, F.; Familletti, P.C.; Pan, Y.C.; Olander, J. V; Connolly, D.T.; Stern, D. Vascular permeability factor: A tumor-derived polypeptide that induces endothelial cell and monocyte procoagulant activity, and promotes monocyte migration. J. Exp. Med. 1990, 172, 1535-1545.

28. Hinz, B. Formation and function of the myofibroblast during tissue repair. J. Investig. Dermatol. 2007, 127, 526-537.

29. Clark, R.A. Fibrin and wound healing. Ann. N. Y. Acad. Sci. 2001, 936, 355-367.

30. Spencer, J.A.; Ferraro, F.; Roussakis, E.; Klein, A.; Wu, J.; Runnels, J.M.; Zaher, W.; Mortensen, J.; Alt, C.; Turcotte, R.; et al. Direct measurement of local oxygen concentration in the bone marrow of live animals. Nature 2014, 508, 269-273.

31. Sitkovsky, M.; Lukashev, D. Regulation of immune cells by local-tissue oxygen tension: HIF1 alpha and adenosine receptors. Nat. Rev. Immunol. 2005, 5, 712-721.

32. Bi, M.; Naczki, C.; Koritzinsky, M.; Fels, D.; Blais, J.; Hu, N.; Harding, H.; Novoa, I.; Varia, M.; Raleigh, J.; et al. ER stress-regulated translation increases tolerance to extreme hypoxia and promotes tumor growth. EMBO J. 2005, 24, 3470-3481.

33. Koritzinsky, M.; Magagnin, M.; van den Beucken, T.; Seigneuric, R.; Savelkouls, K.; Dostie, J.; Pyronnet, S.; Kaufman, R.J.; Weppler, S.A.; Voncken, J.W.; et al. Gene expression during acute and prolonged hypoxia is regulated by distinct mechanisms of translational control. EMBO J. 2006, 25, 1114-1125.

34. Wouters, B.G.; van den Beucken, T.; Magagnin, M.G.; Koritzinsky, M.; Fels, D.; Koumenis, C. Control of the hypoxic response through regulation of mRNA translation. Semin. Cell Dev. Biol. 2005, 16, 487-501.

35. Seta, K.A.; Yuan, Y.; Spicer, Z.; Lu, G.; Bedard, J.; Ferguson, T.K.; Pathrose, P.; Cole-Strauss, A.; Kaufhold, A.; Millhorn, D.E. The role of calcium in hypoxia-induced signal transduction and gene expression. Cell Calcium 2004, 36, 331-340.

36. Arsham, A.M.; Howell, J.J.; Simon, M.C. A novel hypoxia-inducible factor-independent hypoxic response regulating mammalian target of rapamycin and its targets. J. Biol. Chem. 2003, 278, 29655-29660.

37. Lang, K.D.; Kappel, A.; Goodall, G.J. Hypoxia-inducible factor-1alpha mRNA contains an internal ribosome entry site that allows efficient translation during normoxia and hypoxia. Mol. Biol. Cell 2002, 13, 1792-1801.

38. Romero-Ramirez, L.; Cao, H.; Nelson, D.; Hammond, E.; Lee, A.-H.; Yoshida, H.; Mori, K.; Glimcher, L.H.; Denko, N.C.; Giaccia, A.J.; et al. XBP1 is essential for survival under hypoxic conditions and is required for tumor growth. Cancer Res. 2004, 64, 5943-5947.

39. Wang, G.L.; Jiang, B.H.; Rue, E.A.; Semenza, G.L. Hypoxia-inducible factor 1 is a basic-helix-loop-helix-PAS heterodimer regulated by cellular $\mathrm{O} 2$ tension. Proc. Natl. Acad. Sci. USA 1995, 92, 5510-5514.

40. Pugh, C.W.; Rourke, J.F.O.; Nagao, M.; Gleadle, J.M.; Ratcliffe, P.J. Activation of Hypoxia-inducible Factor-1; Definition of Regulatory Domains within the alpha Subunit. J. Biol. Chem. 1997, 272, 11205-11214. 
41. Huang, L.E.; Arany, Z.; Livingston, D.M.; Bunn, H.F. Activation of hypoxia-inducible transcription factor depends primarily upon redox-sensitive stabilization of its alpha subunit. J. Biol. Chem. 1996, 271, 32253-32259.

42. Jiang, B.-H.; Zheng, J.Z.; Leung, S.W.; Roe, R.; Semenza, G.L. Transactivation and Inhibitory Domains of Hypoxia-inducible Factor 1alpha. Modulation of transcriptional activity by oxygen tension. J. Biol. Chem. 1997, 272, 19253-19260.

43. Semenza, G.; Wang, G. A nuclear factor induced by hypoxia via de novo protein synthesis binds to the human erythropoietin gene enhancer at a site required for transcriptional activation. Mol. Cell. Biol. 1992, 12, 5447-5454.

44. Tian, H.; McKnight, S.L.; Russell, D.W. Endothelial PAS domain protein 1 (EPAS1), a transcription factor selectively expressed in endothelial cells. Genes Dev. 1997, 11, 72-82.

45. Makino, Y.; Cao, R.; Svensson, K.; Bertilsson, G.; Asman, M.; Tanaka, H.; Cao, Y.; Berkenstam, A.; Poellinger, L. Inhibitory PAS domain protein is a negative regulator of hypoxia-inducible gene expression. Nature 2001, 414, 550-554.

46. Keith, B.; Adelman, D.M.; Simon, M.C. Targeted mutation of the murine arylhydrocarbon receptor nuclear translocator 2 (Arnt2) gene reveals partial redundancy with Arnt. Proc. Natl. Acad. Sci. USA 2001, 98, 6692-6697.

47. Lisy, K.; Peet, D.J. Turn me on: Regulating HIF transcriptional activity. Cell Death Differ. 2008, $15,642-649$.

48. Kaelin, W.G.; Ratcliffe, P.J. Oxygen sensing by metazoans: The central role of the HIF hydroxylase pathway. Mol. Cell 2008, 30, 393-402.

49. Huang, L.E.; Gu, J.; Schau, M.; Bunn, H.F. Regulation of hypoxia-inducible factor 1alpha is mediated by an O2-dependent degradation domain via the ubiquitin-proteasome pathway. Proc. Natl. Acad. Sci. USA 1998, 95, 7987-7992.

50. Maxwell, P.H.; Wiesener, M.S.; Chang, G.W.; Clifford, S.C.; Vaux, E.C.; Cockman, M.E.; Wykoff, C.C.; Pugh, C.W.; Maher, E.R.; Ratcliffe, P.J. The tumour suppressor protein VHL targets hypoxia-inducible factors for oxygen-dependent proteolysis. Nature 1999, 399, 271-275.

51. Schofield, C.J.; Ratcliffe, P.J. Signalling hypoxia by HIF hydroxylases. Biochem. Biophys. Res. Commun. 2005, 338, 617-626.

52. Wang, G.L.; Semenza, G.L. Characterization of hypoxia-inducible factor 1 and regulation of DNA binding activity by hypoxia. J. Biol. Chem. 1993, 268, 21513-21518.

53. Semenza, G.L. Targeting HIF-1 for cancer therapy. Nat. Rev. Cancer 2003, 3, 721-732.

54. Pouysségur, J.; Dayan, F.; Mazure, N.M. Hypoxia signalling in cancer and approaches to enforce tumour regression. Nature 2006, 441, 437-443.

55. Zagórska, A.; Dulak, J. HIF-1: The knowns and unknowns of hypoxia sensing. Acta Biochim. Pol. 2004, 51, 563-585.

56. Zhong, H.; Chiles, K.; Feldser, D.; Laughner, E.; Hanrahan, C.; Georgescu, M.-M.; Simons, J.W.; Semenza, G.L. Modulation of Hypoxia-inducible Factor 1a expression by epidermal growth factor/phosphatidylinositol 3-kinase/PTEN/AKT/FRAP pathway in human prostate cancer cells: Implications for tumor angiogenesis and therapeutics. Cancer Res. 2000, 60, 1541-1545. 
57. Fukuda, R.; Hirota, K.; Fan, F.; Jung, Y.D.; Ellis, L.M.; Semenza, G.L. Insulin-like growth factor 1 induces hypoxia-inducible factor 1-mediated vascular endothelial growth factor expression, which is dependent on MAP kinase and phosphatidylinositol 3-kinase signaling in colon cancer cells. J. Biol. Chem. 2002, 277, 38205-38211.

58. Richard, D.E.; Berra, E.; Gothié, E.; Roux, D.; Pouysségur, J. p42/p44 Mitogen-activated protein kinases phosphorylate hypoxia-inducible factor 1alpha (HIF-1alpha) and enhance the transcriptional activity of HIF-1. J. Biol. Chem. 1999, 274, 32631-32637.

59. Wang, G.L.; Jiang, B.H.; Semenza, G.L. Effect of protein kinase and phosphatase inhibitors on expression of hypoxia-inducible factor 1. Biochem. Biophys. Res. Commun. 1995, 216, 669-675.

60. HIF NIH3T3 Reporter Stable Cell Line. Available online: http://www.affymetrix.com/catalog/ prod660088/USB/HIF+NIH3T3+Reporter+Stable\#1_1 (accessed on 30 October 2014).

61. Tang, N.; Wang, L.; Esko, J.; Giordano, F.J.; Huang, Y.; Gerber, H.-P.; Ferrara, N.; Johnson, R.S. Loss of HIF-1alpha in endothelial cells disrupts a hypoxia-driven VEGF autocrine loop necessary for tumorigenesis. Cancer Cell 2004, 6, 485-495.

62. Wang, V.; Davis, D.A.; Haque, M.; Huang, L.E.; Yarchoan, R. Differential gene up-regulation by hypoxia-inducible factor-1alpha and hypoxia-inducible factor-2alpha in HEK293T cells. Cancer Res. 2005, 65, 3299-3306.

63. Hu, C.-J.; Sataur, A.; Wang, L.; Chen, H.; Simon, M.C. The N-terminal transactivation domain confers target gene specificity of hypoxia-inducible factors HIF-1alpha and HIF-2alpha. Mol. Biol. Cell 2007, 18, 4528-4542.

64. Yamashita, T.; Ohneda, O.; Nagano, M.; Iemitsu, M.; Makino, Y.; Tanaka, H.; Miyauchi, T.; Goto, K.; Ohneda, K.; Fujii-Kuriyama, Y.; et al. Abnormal heart development and lung remodeling in mice lacking the hypoxia-inducible factor-related basic helix-loop-helix PAS protein NEPAS. Mol. Cell. Biol. 2008, 28, 1285-1297.

65. Heikkilä, M.; Pasanen, A.; Kivirikko, K.I.; Myllyharju, J. Roles of the human hypoxia-inducible factor (HIF)-3 $\alpha$ variants in the hypoxia response. Cell. Mol. Life Sci. 2011, 68, 3885-3901.

66. Hu, C.-J.; Wang, L.-Y.; Chodosh, L.A.; Keith, B.; Simon, C.M. Differential roles of hypoxia-inducible factor $1 \alpha(\mathrm{HIF}-1 \alpha)$ and HIF-2 $\alpha$ in hypoxic gene regulation. Mol. Cell. Biol. 2003, 23, 9361-9374.

67. Iyer, N.V.; Kotch, L.E.; Agani, F.; Leung, S.W.; Laughner, E.; Wenger, R.H.; Gassmann, M.; Gearhart, J.D.; Lawler, A.M.; Yu, A.Y.; et al. Cellular and developmental control of $\mathrm{O}_{2}$ homeostasis by hypoxia-inducible factor 1alpha. Genes Dev. 1998, 12, 149-162.

68. Scortegagna, M.; Ding, K.; Oktay, Y.; Gaur, A.; Thurmond, F.; Yan, L.-J.; Marck, B.T.; Matsumoto, A.M.; Shelton, J.M.; Richardson, J.A.; et al. Multiple organ pathology, metabolic abnormalities and impaired homeostasis of reactive oxygen species in Epas1-/- mice. Nat. Genet. 2003, 35, 331-340.

69. Bertout, J.A.; Majmundar, A.J.; Gordan, J.D.; Lam, J.C.; Ditsworth, D.; Keith, B.; Brown, E.J.; Nathanson, K.L.; Simon, M.C. HIF2alpha inhibition promotes p53 pathway activity, tumor cell death, and radiation responses. Proc. Natl. Acad. Sci. USA 2009, 106, 14391-14396.

70. Skuli, N.; Liu, L.; Runge, A.; Wang, T.; Yuan, L.; Patel, S.; Iruela-Arispe, L.; Simon, M.C.; Keith, B. Endothelial deletion of hypoxia-inducible factor-2alpha (HIF-2alpha) alters vascular function and tumor angiogenesis. Blood 2009, 114, 469-477. 
71. Compernolle, V.; Brusselmans, K.; Franco, D.; Moorman, A.; Dewerchin, M.; Collen, D.; Carmeliet, P. Cardia bifida, defective heart development and abnormal neural crest migration in embryos lacking hypoxia-inducible factor-1 $\alpha$. Cardiovasc. Res. 2003, 60, 569-579.

72. Ryan, H.E.; Lo, J.; Johnson, R.S. HIF-1 alpha is required for solid tumor formation and embryonic vascularization. EMBO J. 1998, 17, 3005-3015.

73. Kotch, L.E.; Iyer, N.V; Laughner, E.; Semenza, G.L. Defective vascularization of HIF-1alpha-null embryos is not associated with VEGF deficiency but with mesenchymal cell death. Dev. Biol. 1999, 209, 254-267.

74. Carmeliet, P.; Dor, Y.; Herbert, J.; Fukumura, D.; Brusselmans, K.; Dewerchin, M.; Neeman, M.; Bono, F.; Abramovitch, R.; Maxwell, P.; et al. Role of HIF-1alpha in hypoxia-mediated apoptosis, cell proliferation and tumour angiogenesis. Nature 1998, 394, 485-490.

75. Yu, A.Y.; Shimoda, L.A.; Iyer, N.V.; Huso, D.L.; Sun, X.; McWilliams, R.; Beaty, T.; Sham, J.S.K.; Wiener, C.M.; Sylvester, J.T.; et al. Impaired physiological responses to chronic hypoxia in mice partially deficient for hypoxia-inducible factor 1a. J. Clin. Investig. 1999, 103, 691-696.

76. Skuli, N.; Majmundar, A.J.; Krock, B.L.; Mesquita, R.C.; Mathew, L.K.; Quinn, Z.L.; Runge, A.; Liu, L.; Kim, M.N.; Liang, J.; et al. Endothelial HIF-2 $\alpha$ regulates murine pathological angiogenesis and revascularization processes. J. Clin. Investig. 2012, 122, 1427-1443.

77. Tian, H.; Hammer, R.E.; Matsumoto, A.M.; Russell, D.W.; McKnight, S.L. The hypoxia-responsive transcription factor EPAS1 is essential for catecholamine homeostasis and protection against heart failure during embryonic development. Genes Dev. 1998, 12, 3320-3324.

78. Cowburn, A.; Alexander, L.; Southwood, M.; Nizet, V.; Chilvers, E.; Johnson, R. Epidermal Deletion of HIF-2 $\alpha$ Stimulates Wound Closure. J. Investig. Dermatol. 2014, 134, 801-808.

79. Peng, J.; Zhang, L.; Drysdale, L.; Fong, G.H. The transcription factor EPAS-1/hypoxia-inducible factor 2alpha plays an important role in vascular remodeling. Proc. Natl. Acad. Sci. USA 2000, 97, 8386-8391.

80. Duan, L.-J.; Zhang-Benoit, Y.; Fong, G.-H. Endothelium-intrinsic requirement for Hif-2alpha during vascular development. Circulation 2005, 111, 2227-2232.

81. Compernolle, V.; Brusselmans, K.; Acker, T.; Hoet, P.; Tjwa, M.; Beck, H.; Plaisance, S.; Dor, Y.; Keshet, E.; Lupu, F.; et al. Loss of HIF-2alpha and inhibition of VEGF impair fetal lung maturation, whereas treatment with VEGF prevents fatal respiratory distress in premature mice. Nat. Med. 2002, 8, 702-710.

82. Gruber, M.; Hu, C.; Johnson, R.S.; Brown, E.J.; Keith, B.; Simon, M.C. Acute postnatal ablation of Hif-2a results in anemia. Proc. Natl. Acad. Sci. USA 2007, 104, 2301-2306.

83. Brusselmans, K.; Compernolle, V.; Tjwa, M.; Wiesener, M.S.; Maxwell, P.H.; Collen, D.; Carmeliet, P. Heterozygous deficiency of hypoxia-inducible factor- $2 \alpha$ protects mice against pulmonary hypertension and right ventricular dysfunction during prolonged hypoxia. J. Clin. Investig. 2003, 111, 1519-1527.

84. Dioum, E.M.; Clarke, S.L.; Ding, K.; Repa, J.J.; Garcia, J.A. HIF-2alpha-haploinsufficient mice have blunted retinal neovascularization due to impaired expression of a proangiogenic gene battery. Investig. Ophthalmol. Vis. Sci. 2008, 49, 2714-2720. 
85. Tanaka, T.; Wiesener, M.; Bernhardt, W.; Eckardt, K.-U.; Warnecke, C. The human HIF (hypoxia-inducible factor)-3alpha gene is a HIF-1 target gene and may modulate hypoxic gene induction. Biochem. J. 2009, 424, 143-151.

86. Kozak, K.; Abbott, B.; Hankinson, O. ARNT-deficient mice and placental differentiation. Dev. Biol. 1997, 191, 297-305.

87. Maltepe, E.; Schmidt, J.V.; Baunoch, D.; Bradfield, C.A.; Simon, M.C. Abnormal angiogenesis and responses to glucose and oxygen deprivation in mice lacking the protein ARNT. Nature 1997, 386, 403-407.

88. Adelman, D.; Maltepe, E.; Simon, M. Multilineage embryonic hematopoiesis requires hypoxic ARNT activity. Genes Dev. 1999, 13, 2478-2483.

89. Adelman, D.; Gertsenstein, M.; Nagy, A.; Simon, M.; Maltepe, E. Placental cell fates are regulated in vivo by HIF-mediated hypoxia responses. Genes Dev. 2000, 14, 3191-3203.

90. Ramírez-Bergeron, D.L.; Runge, A.; Adelman, D.M.; Gohil, M.; Simon, M.C. HIF-Dependent hematopoietic factors regulate the development of the embryonic vasculature. Dev. Cell 2006, $11,81-92$.

91. Yim, S.; Shah, Y.; Tomita, S.; Morris, H.; Gavrilova, O.; Lambert, G.; Ward, J.; Gonzalez, F. Disruption of the Arnt gene in endothelial cells causes hepatic vascular defects and partial embryonic lethality in mice. Hepatology 2006, 44, 550-560.

92. Albina, J.E.; Mastrofrancesco, B.; Vessella, J.A.; Louis, C.A.; Henry, W.L.; Reichner, J.S. HIF-1 expression in healing wounds: HIF-1alpha induction in primary inflammatory cells by TNF-alpha. Am. J. Physiol. Cell Physiol. 2001, 281, C1971-C1977.

93. Haroon, Z.A.; Raleigh, J.A.; Greenberg, C.S.; Dewhirst, M.W. Early wound healing exhibits cytokine surge without evidence of hypoxia. Ann. Surg. 2000, 231, 137-147.

94. Peyssonnaux, C.; Cejudo-Martin, P.; Doedens, A.; Zinkernagel, A.S.; Johnson, R.S.; Nizet, V. Cutting edge: Essential role of hypoxia inducible factor-1alpha in development of lipopolysaccharide-induced sepsis. J. Immunol. 2007, 178, 7516-7519.

95. Imtiyaz, H.Z.; Williams, E.P.; Hickey, M.M.; Patel, S.A.; Durham, A.C.; Yuan, L.-J.; Hammond, R.; Gimotty, P.A.; Keith, B.; Simon, M.C. Hypoxia-inducible factor 2alpha regulates macrophage function in mouse models of acute and tumor inflammation. J. Clin. Investig. 2010, 120, 2699-2714.

96. Elson, D.; Ryan, H.; Snow, J.; Johnson, R.; Arbeit, J. Coordinate up-regulation of hypoxia inducible factor (HIF)-1 $\alpha$ and HIF-1 target genes during multi-stage epidermal carcinogenesis and wound healing. Cancer Res. 2000, 21, 6189-6195.

97. Zhang, X.; Liu, L.; Wei, X.; Tan, Y.S.; Tong, L.; Chang, R.; Ghanamah, M.S.; Reinblatt, M.; Marti, G.P.; Harmon, J.W.; et al. Impaired angiogenesis and mobilization of circulating angiogenic cells in HIF-1alpha heterozygous-null mice after burn wounding. Wound Repair Regen. 2010, 18, 193-201.

98. Zhang, X.; Sarkar, K.; Rey, S.; Sebastian, R.; Andrikopoulou, E.; Marti, G.P.; Fox-Talbot, K.; Semenza, G.L.; Harmon, J.W. Aging impairs the mobilization and homing of bone marrow-derived angiogenic cells to burn wounds. J. Mol. Med. 2011, 89, 985-995.

99. Sarkar, K.; Rey, S.; Zhang, X.; Sebastian, R.; Marti, G.P.; Fox-Talbot, K.; Cardona, A.V.; Du, J.; Tan, Y.S.; Liu, L.; et al. Tie2-dependent knockout of HIF-1 impairs burn wound vascularization and homing of bone marrow-derived angiogenic cells. Cardiovasc. Res. 2012, 93, 162-169. 
100. Baatar, D.; Jones, M.K.; Tsugawa, K.; Pai, R.; Moon, W.S.; Koh, G.Y.; Kim, I.; Kitano, S.; Tarnawski, A.S. Esophageal ulceration triggers expression of hypoxia-inducible factor-1 alpha and activates vascular endothelial growth factor gene: Implications for angiogenesis and ulcer healing. Am. J. Pathol. 2002, 161, 1449-1457.

101. Szabo, I.L.; Kawanaka, H.; Jones, M.K.; Pai, R.; Soreghan, B.A.; Baatar, D.; Husain, S.S.; Tarnawski, A.S. Activation of hypoxia inducible factor-1alpha in gastric mucosa in response to ethanol injury: A trigger for angiogenesis? Life Sci. 2001, 69, 3035-3044.

102. Alizadeh, N.; Pepper, M.S.; Modarressi, A.; Alfo, K.; Schlaudraff, K.; Montandon, D.; Gabbiani, G.; Bochaton-Piallat, M.-L.; Pittet, B. Persistent ischemia impairs myofibroblast development in wound granulation tissue: A new model of delayed wound healing. Wound Repair Regen. 2007, 15, 809-816.

103. Botusan, I.; Sunkari, V.; Savu, O.; Catrina, A.; Grünler, J.; Lindberg, S.; Pereira, T.; Ylä-Herttuala, S.; Poellinger, L.; Brismar, K.; et al. Stabilization of HIF-1 $\alpha$ is critical to improve wound healing in diabetic mice. Proc. Natl. Acad. Sci. USA 2008, 105, 19426-19431.

104. Chang, E.I.; Loh, S.A.; Ceradini, D.J.; Chang, E.I.; Lin, S.; Bastidas, N.; Aarabi, S.; Chan, D.A.; Freedman, M.L.; Giaccia, A.J.; et al. Age decreases endothelial progenitor cell recruitment through decreases in hypoxia-inducible factor 1alpha stabilization during ischemia. Circulation 2007, 116, 2818-2829.

105. Mace, K.A.; Yu, D.H.; Paydar, K.Z.; Boudreau, N.; Young, D.M. Sustained expression of Hif-1 $\alpha$ in the diabetic environment promotes angiogenesis and cutaneous wound repair. Wound Repair Regen. 2007, 15, 636-645.

106. Catrina, S.-B.; Okamoto, K.; Pereira, T.; Brismar, K.; Poellinger, L. Hyperglycemia regulates hypoxia-inducible factor-1 alpha protein stability and function. Diabetes 2004, 53, 3226-3232.

107. Thangarajah, H.; Yao, D.; Chang, E.I.; Shi, Y.; Jazayeri, L.; Vial, I.N.; Galiano, R.D.; Du, X.-L.; Grogan, R.; Galvez, M.G.; et al. The molecular basis for impaired hypoxia-induced VEGF expression in diabetic tissues. Proc. Natl. Acad. Sci. USA 2009, 106, 13505-13510.

108. Liu, L.; Marti, G.P.; Wei, X.; Zhang, X.; Zhang, H.; Liu, Y.V; Nastai, M.; Semenza, G.L.; Harmon, J.W. Age-dependent impairment of HIF-1alpha expression in diabetic mice: Correction with electroporation-facilitated gene therapy increases wound healing, angiogenesis, and circulating angiogenic cells. J. Cell. Physiol. 2008, 217, 319-327.

109. Kellner, K.; Liebsch, G.; Klimant, I.; Wolfbeis, O.S.; Blunk, T.; Schulz, M.B.; Göpferich, A. Determination of oxygen gradients in engineered tissue using a fluorescent sensor. Biotechnol. Bioeng. 2002, 80, 73-83.

110. Schechner, J.S.; Nath, A.K.; Zheng, L.; Kluger, M.S.; Hughes, C.C.; Sierra-Honigmann, M.R.; Lorber, M.I.; Tellides, G.; Kashgarian, M.; Bothwell, A.L.; et al. In vivo formation of complex microvessels lined by human endothelial cells in an immunodeficient mouse. Proc. Natl. Acad. Sci. USA 2000, 97, 9191-9196.

111. Tonnesen, M.G.; Feng, X.; Clark, R.A. Angiogenesis in wound healing. J. Investig. Dermatol. Symp. Proc. 2000, 5, 40-46.

112. Croll, T.I.; Gentz, S.; Mueller, K.; Davidson, M.; O’Connor, A.J.; Stevens, G.W.; Cooper-White, J.J. Modelling oxygen diffusion and cell growth in a porous, vascularising scaffold for soft tissue engineering applications. Chem. Eng. Sci. 2005, 60, 4924-4934. 
113. Holder, W.D., Jr.; Gruber, H.E.; Roland, W.D.; Moore, A.L.; Culberson, C.R.; Loebsack, A.B.; Burg, K.J.L.; Mooney, D.J. Increased vascularization and heterogeneity of vascular structures occurring in polyglycolide matrices containing aortic endothelial cells implanted in the rat. Tissue Eng. 1997, 3, 149-160.

114. Mancuso, M.R.; Davis, R.; Norberg, S.M.; O’Brien, S.; Sennino, B.; Nakahara, T.; Yao, V.J.; Inai, T.; Brooks, P.; Freimark, B.; et al. Rapid vascular regrowth in tumors after reversal of VEGF inhibition. J. Clin. Investig. 2006, 116, 2610-2621.

115. Hashizume, H.; Baluk, P.; Morikawa, S.; McLean, J.W.; Thurston, G.; Roberge, S.; Jain, R.K.; McDonald, D.M. Openings between defective endothelial cells explain tumor vessel leakiness. Am. J. Pathol. 2000, 156, 1363-1380.

116. Goel, S.; Duda, D.G.; Xu, L.; Munn, L.L.; Boucher, Y.; Fukumura, D.; Jain, R.K. Normalization of the vasculature for treatment of cancer and other diseases. Physiol. Rev. 2011, 91, 1071-1121.

117. Höckel, M.; Schlenger, K.; Mitze, M.; Schäffer, U.; Vaupel, P. Hypoxia and Radiation Response in Human Tumors. Semin. Radiat. Oncol. 1996, 6, 3-9.

118. Pàez-Ribes, M.; Allen, E.; Hudock, J.; Takeda, T.; Okuyama, H.; Viñals, F.; Inoue, M.; Bergers, G.; Hanahan, D.; Casanovas, O. Antiangiogenic therapy elicits malignant progression of tumors to increased local invasion and distant metastasis. Cancer Cell 2009, 15, 220-231.

119. Bloch, W.; Huggel, K.; Sasaki, T.; Grose, R.; Bugnon, P.; Addicks, K.; Timpl, R.; Werner, S. The angiogenesis inhibitor endostatin impairs blood vessel maturation during wound healing. FASEB J. 2000, 14, 2373-2376.

120. Semenza, G.L. Vascular responses to hypoxia and ischemia. Arterioscler. Thromb. Vasc. Biol. 2010, 30, 648-652.

121. Ozaki, H.; Hayashi, H.; Vinores, S.A.; Moromizato, Y.; Campochiaro, P.A.; Oshima, K. Intravitreal sustained release of VEGF causes retinal neovascularization in rabbits and breakdown of the blood-retinal barrier in rabbits and primates. Exp. Eye Res. 1997, 64, 505-517.

122. Thurston, G.; Suri, C.; Smith, K.; McClain, J.; Sato, T.N.; Yancopoulos, G.D.; McDonald, D.M. Leakage-resistant blood vessels in mice transgenically overexpressing angiopoietin-1. Science 1999, 286, 2511-2514.

123. Vranckx, J.J.; Yao, F.; Petrie, N.; Augustinova, H.; Hoeller, D.; Visovatti, S.; Slama, J.; Eriksson, E. In vivo gene delivery of Ad-VEGF121 to full-thickness wounds in aged pigs results in high levels of VEGF expression but not in accelerated healing. Wound Repair Regen. 2005, 13, 51-60.

124. Sánchez Muñoz, I.; Granados, R.; Holguín Holgado, P.; García Vela, J.A.; Casares, C.; Casares, M. The use of adipose mesenchymal stem cells and human umbilical vascular endothelial cells on a fibrin matrix for endothelialized skin substitue. Tissue Eng. Part A 2014, doi:10.1089/ten.tea.2013.0626.

125. Ghajar, C.M.; Chen, X.; Harris, J.W.; Suresh, V.; Hughes, C.C.W.; Jeon, N.L.; Putnam, A.J.; George, S.C. The effect of matrix density on the regulation of 3-D capillary morphogenesis. Biophys. J. 2008, 94, 1930-1941.

126. Tremblay, P.-L.; Hudon, V.; Berthod, F.; Germain, L.; Auger, F.A. Inosculation of tissue-engineered capillaries with the host's vasculature in a reconstructed skin transplanted on mice. Am. J. Transplant. 2005, 5, 1002-1010. 
127. Griffith, C.K.; George, S.C. The effect of hypoxia on in vitro prevascularization of a thick soft tissue. Tissue Eng. Part A 2009, 15, 2423-2434.

128. Siddiqui, A.; Galiano, R.D.; Connors, D.; Gruskin, E.; Wu, L.; Mustoe, T.A. Differential effects of oxygen on human dermal fibroblasts: Acute versus chronic hypoxia. Wound Repair Regen. 1996, 4, 211-218.

129. O’Toole, E.A.; Marinkovich, M.P.; Peavey, C.L.; Amieva, M.R.; Furthmayr, H.; Mustoe, T.A.; Woodley, D.T. Hypoxia increases human keratinocyte motility on connective tissue. J. Clin. Investig. 1997, 100, 2881-2891.

130. Tandara, A.; Mustoe, T. Oxygen in wound healing--more than a nutrient. World J. Surg. 2004, 28, 294-300.

131. Wu, L.; Xia, Y.P.; Roth, S.I.; Gruskin, E.; Mustoe, T.A. Transforming growth factor-beta1 fails to stimulate wound healing and impairs its signal transduction in an aged ischemic ulcer model: Importance of oxygen and age. Am. J. Pathol. 1999, 154, 301-309.

132. Ahn, S.T.; Mustoe, T.A. Effects of ischemia on ulcer wound healing: A new model in the rabbit ear. Ann. Plast. Surg. 1990, 24, 17-23.

133. Biswas, S.; Roy, S.; Banerjee, J.; Hussain, S.-R.A.; Khanna, S.; Meenakshisundaram, G.; Kuppusamy, P.; Friedman, A.; Sen, C.K. Hypoxia inducible microRNA 210 attenuates keratinocyte proliferation and impairs closure in a murine model of ischemic wounds. Proc. Natl. Acad. Sci. USA 2010, 107, 6976-6981.

134. Allen, D.B.; Maguire, J.J.; Mahdavian, M.; Wicke, C.; Marcocci, L.; Scheuenstuhl, H.; Chang, M.; Le, A.X.; Hopf, H.W.; Hunt, T.K. Wound hypoxia and acidosis limit neutrophil bacterial killing mechanisms. Arch. Surg. 1997, 132, 991-996.

135. Knighton, D.R.; Halliday, B.; Hunt, T.K. Oxygen as an Antibiotic. The Effect of Inspired oxygen on infection. Arch. Surg. 1984, 119, 199-204.

136. Knighton, D.R.; Fiegel, V.D.; Halverson, T.; Schneider, S.; Brown, T.; Wells, C.L. Oxygen as an Antibiotic. The Effect of Inspired Oxygen on Bacterial Clearance. Arch. Biochem. Biophys. 1990, 125, 97-100.

137. Nakajima, T.; Nakajima, E.; Shearer, T.R.; Azuma, M. Concerted inhibition of HIF-1 $\alpha$ and $-2 \alpha$ expression markedly suppresses angiogenesis in cultured RPE cells. Mol. Cell. Biochem. 2013, 383, 113-122.

138. Kelly, B.D.; Hackett, F.; Hirota, K.; Oshima, Y.; Cai, Z.; Berg-Dixon, S.; Rowan, A.; Yan, Z.; Campochiaro, P.A.; Semenza, G.L. Cell type-specific regulation of angiogenic growth factor gene expression and induction of angiogenesis in nonischemic tissue by a constitutively active form of hypoxia-inducible factor 1. Circ. Res. 2003, 93, 1074-1081.

139. Elson, D.A.; Thurston, G.; Huang, L.E.; Ginzinger, D.E.; McDonald, D.; Johnson, R.S.; Arbeit, J.M. Induction of hypervascularity without leakage or inflammation in transgenic mice overexpressing hypoxia-inducible factor-1alpha. Genes Dev. 2001, 15, 2520-2532.

140. Li, J.; Post, M.; Volk, R.; Gao, Y.; Li, M.; Metais, C.; Sato, K.; Tsai, J.; Aird, W.; Rosenberg, R. D.; et al. PR39, a peptide regulator of angiogenesis. Nat. Med. 2000, 6, 49-55.

141. Linden, T.; Katschinski, D.M.; Eckhardt, K.; Scheid, A.; Pagel, H.; Wenger, R.H. The antimycotic ciclopirox olamine induces HIF-1alpha stability, VEGF expression, and angiogenesis. FASEB J. 2003, 17, 761-763. 
142. Pajusola, K.; Künnapuu, J.; Vuorikoski, S.; Soronen, J.; André, H.; Pereira, T.; Korpisalo, P.; Ylä-Herttuala, S.; Poellinger, L.; Alitalo, K. Stabilized HIF-1alpha is superior to VEGF for angiogenesis in skeletal muscle via adeno-associated virus gene transfer. FASEB J. 2005, 19, 1365-1367.

143. Trentin, D.; Hall, H.; Wechsler, S.; Hubbell, J.A. Peptide-matrix-mediated gene transfer of an variant for local induction of angiogenesis. Proc. Natl. Acad. Sci. USA 2006, 103, 2506-2511.

144. Distler, J.H.W.; Jüngel, A.; Pileckyte, M.; Zwerina, J.; Michel, B.A.; Gay, R.E.; Kowal-Bielecka, O.; Matucci-Cerinic, M.; Schett, G.; Marti, H.H.; et al. Hypoxia-induced increase in the production of extracellular matrix proteins in systemic sclerosis. Arthritis Rheumatol. 2007, 56, 4203-4215.

145. Aarabi, S.; Longaker, M.T.; Gurtner, G.C. Hypertrophic scar formation following burns and trauma: New approaches to treatment. PLoS Med. 2007, 4, e234.

146. Bertout, J.A.; Patel, S.A.; Simon, M.C. The impact of $\mathrm{O} 2$ availability on human cancer. Nat. Rev. Cancer 2008, 8, 967-975.

147. Maxwell, P.H. The HIF pathway in cancer. Semin. Cell Dev. Biol. 2005, 16, 523-530.

148. Melillo, G. Targeting hypoxia cell signaling for cancer therapy. Cancer Metastasis Rev. 2007, 26, 341-352.

149. Lee, K.A.; Qian, D.Z.; Rey, S.; Wei, H.; Liu, J.O.; Semenza, G.L. Anthracycline chemotherapy inhibits HIF-1 transcriptional activity and tumor-induced mobilization of circulating angiogenic cells. Proc. Natl. Acad. Sci. USA 2009, 106, 2353-2358.

150. Nagel, S.; Talbot, N.P.; Mecinović, J.; Smith, T.G.; Buchan, A.M.; Schofield, C.J. Therapeutic manipulation of the HIF hydroxylases. Antioxid. Redox Signal. 2010, 12, 481-501.

151. Hsieh, M.M.; Linde, N.S.; Wynter, A.; Metzger, M.; Wong, C.; Langsetmo, I.; Lin, A.; Smith, R.; Rodgers, G.P.; Donahue, R.E.; et al. HIF prolyl hydroxylase inhibition results in endogenous erythropoietin induction, erythrocytosis, and modest fetal hemoglobin expression in rhesus macaques. Blood 2007, 110, 2140-2147.

152. Wei, Y.; Gong, J.; Thimmulappa, R.K.; Kosmider, B.; Biswal, S.; Duh, E.J. Nrf2 acts cell-autonomously in endothelium to regulate tip cell formation and vascular branching. Proc. Natl. Acad. Sci. USA 2013, 110, E3910-E3918.

153. Chen, L.; Endler, A.; Uchida, K.; Horiguchi, S.; Morizane, Y.; Iijima, O.; Toi, M.; Shibasaki, F. Int6/eIF3e silencing promotes functional blood vessel outgrowth and enhances wound healing by upregulating hypoxia-induced factor 2alpha expression. Circulation 2010, 122, 910-919.

154. Van Weel, V.; Seghers, L.; de Vries, M.R.; Kuiper, E.J.; Schlingemann, R.O.; Bajema, I.M.; Lindeman, J.H.N.; Delis-van Diemen, P.M.; van Hinsbergh, V.W.M.; van Bockel, J.H.; et al. Expression of vascular endothelial growth factor, stromal cell-derived factor-1, and CXCR4 in human limb muscle with acute and chronic ischemia. Arterioscler. Thromb. Vasc. Biol. 2007, 27, 1426-1432.

(C) 2014 by the authors; licensee MDPI, Basel, Switzerland. This article is an open access article distributed under the terms and conditions of the Creative Commons Attribution license (http://creativecommons.org/licenses/by/4.0/). 